\title{
Armand Robin e a não tradução
}

\author{
Maria Emília Pereira Chanut
}

\section{A Vida de Armand Robin}

Os que conhecem Armand Robin (1912-1961) por terem lido Ma vie sans moi (1970) o descobriram, paradoxalmente, por uma parte de seu trabalho poético à qual ele havia renunciado muito cedo.' Tornado figura emblemática do anticomunismo, a grande divulgação, a partir do final dos anos 70, do estereótipo do poeta maldito contribuiu para a construção de uma mitologia cativante: uma biografia inventada, hoje o sabemos, prefaciava um livro fabricado de forma obscura e arbitrária, a partir de fragmentos póstumos encontrados e recolhidos pelo "amigo editor" em seu apartamento (Le monde d'une voix, 1970). ${ }^{2}$

Nascido na Bretanha, na época em que se iniciava o grande desmantelamento da sociedade rural tradicional, Robin aprendeu a nomear em bretão a natureza que o rodeava, quase inalterada desde a ldade Média. A vida no campo, como tantos poemas a descrevem, era dura demais e, por essa razão, as palavras raramente saíam da boca dos camponeses. A opção de Robin pelos estudos foi, portanto, sempre vivida por ele como uma traição, tanto pela renúncia à língua materna como ao trabalho na terra. Um fragmento o testemunha: "Surgido daqueles que não tem 
palavras para seus gritos, tenho ao menos, para abrandar meus remorsos, semeado de língua em língua minhas palavras" (apud Morvan, 1979, p. 9). Abominando ser um intelectual francês, recusou o acesso à burguesia e desprezou a carreira convencional que the propunha a universidade. Nem francês nem bretão, nem burguês nem proletário, Robin perde definitivamente suas raízes e sua identidade, e é essa situação dramática de dépaysement que determina todo o seu trabalho e sua pulsão politradutória em direção à poesia do outro.

interesse pelas línguas estrangeiras, manifestado desde muito cedo em sua formação escolar, torna-se para Robin a ocasião de um grande trauma: após estudar o russo durante dois anos, viaja para a Rússia em 1934 e suas convicções comunistas, antes fortalecidas pelo sentimento de ter encontrado a "pátria de eleição" de André Gide (apud Morvan, 1979, p. 11) desabam diante do sofrimento e da pobreza do proletariado russo. A dor da decepção, agravada pelo choque da morte de sua mãe alguns meses antes, aniquilam definitivamente Robin.

O que se vê, portanto, é a realização, entre 1936 e 1942, de uma obra de crítica literária originalíssima e uma obra de tradutor que equipara Robin aos melhores tradutores de seu tempo. ${ }^{3}$ Simultaneamente, a coletânea de poemas e o único romance publicados faziam dele um escritor que Maurice Blanchot considerava com o mesmo interesse que Sartre e Camus, colocando-o entre os escritores que começavam a publicar com qualidade. Em suma, se em 1942 Armand Robin é um escritor em rápida ascensão, em 1943 não é mais ninguém. Isolado e afastado do meio literário, algumas de suas cartas e outros escritos anunciam o início de um período depressivo e de um desejo de autodestruição e destruição da própria obra literária, como sugere esse fragmento (in: Armand Robin: La quête de l'universel, 1989): 
Que o que eu crie seja publicado ou não tornou-se inteiramente indiferente para mim (...) Se eu desaparecer, que tenha ao menos o triste prazer de des-aparecer inteiro, levado para um abismo sem nome. Nada será encontrado depois de mim, posso garanti-lo (...) Tudo o que escrevi nos últimos tempos me escapa a cada instante, tendendo cada vez para outra coisa; parece-me às vezes ter partido para um país, longe, muito longe de qualquer passado. Então, não sei mais de nada. (p. 27)

O retorno à atividade literária, em 1949, é marcado pela publicação de Quatre Poètes Russes (Maïakovski, Pasternak, Blok, lesssiênin), pela Éditions du Seuil. A mesma editora confirma o seu retorno dois anos depois publicando as traduções do poeta húngaro André Ady. E é nessa época que a grande atuação de Robin se orienta numa nova direção, aventurando-se na criação da emissão radiofônica que intitulou Poésie sans passeport. Os anos de 1951 e 1952 são tragicamente marcados pelas mortes de André Gide e de Paul Éluard, respectivamente; ao primeiro, Robin dedica uma tradução d'Ernst Jirgal: Elégie de Gide, publicada pela NRF; ao segundo, um artigo publicado no Le Libertaire.

La fausse parole inaugura um grande ano de publicações, em 1953. A obra retoma diversos artigos surgidos nos anos anteriores, ponto de conclusão da reflexão sobre as escutas de rádios e da propaganda russa. Reeditado em 1979 e 2002, pela Le temps qu'il fait, esse ensaio de natureza político-libertária, considerado a obra prima em prosa do poeta, revela um texto profético, tanto pela denúncia das engrenagens da estratégia de propaganda comunista, quanto pela intuição dos malefícios de uma globalização veiculada pelas poderosas mídias. O tema da "perda consentida dos sentidos das palavras" iá estava presente desde 1945, quando a Federação Anarquista publicava Les Poèmes indésirables, distribuídos de mão em mão pelo próprio Robin.

Ainda em 1953, publica a coletânea de suas traduções, com o título de Poésie Non Traduite. Terminam definitivamente as emis- 
sões de poesia, Poésie Sans Passeport, mas Robin continua a freqüentar a rádio, notadamente participando de Belles Lettres. Ele participa do surgimento da nova NRF que passa a se chamar Nouvelle Nouvelle Revue Française (NNRF) e sua primeira colaboração são as traduções de 4 poemas de Ungaretti. Esse ritmo de duas a quatro publicações anuais prossegue até 1958, o mais freqüentemente sob a forma de traduções. Em 1954, inicia colaboração em La Parisienne, onde publica um artigo polêmico: Se garer des revoltes, no qual ele define seu ideal de escritor livre, decepcionado sem dúvida, mas fiel a suas convicções originais: "Os verdadeiros poetas vivem e criam com antecedência em seu tempo. [...] Nenhuma tática, nenhuma estratégia, nenhuma astúcia, nenhum temor da pobreza, nenhuma preocupação com a fama. Em todos os planos, uma independência total com relação a tudo" (1989, p. 43). Participa do número especial da NNRF em homenagem a Supervielle, um grande amigo seu.

Robin continua a traduzir muito nesse período até 1957, do espanhol, do árabe, de várias línguas eslavas e, principalmente, do polonês. Poésie Non Traduite Il é publicada em 1958 e, a partir de então, quase todas as outras traduções de Robin aparecerão na Gazette de Lausanne. É também a partir desse ano que ele começa a publicar as traduções de Shakespeare para a coleção bilíngüe do Club Français du Livre, especialmente Les Gaillardes Epouses de Windsor e Othello e, em 1960, Le Roi Lear. Suas últimas traduções são três poemas de Max Ernst para a Gazette de Lausanne.

Robin prosseguiu assim, traduzindo cada vez mais poetas de diversas e longínquas línguas, mostrando-se incapaz de retornar a si mesmo. Se, por um lado, os fragmentos póstumos revelam a precariedade dos textos apenas esboçados, nunca publicados nem lidos por ninguém - "todos meus poemas são ensaios", ele escreve -, eles têm ao menos o grande mérito de testemunharem o processo germinal de uma obra que não teve 
prosseguimento. Gravemente doente já há pelo menos dois anos, Armand Robin falece em 29 de março de 1961, aos 49 anos de idade, abandonado numa enfermaria de Paris, em circunstâncias misteriosas.

A não tradução como ato de marginalidade: à margem da margem.

O discurso da não tradução remete de imediato ao inverossímil, uma vez que se alguém traduz e diz não traduzir estaria contrariando a verdade do que faz. Mas de que verdade se trata nessa não tradução? A renomeação é sempre um ato crítico, uma estratégia de ressignificação. No caso do poeta politradutor bretão Armand Robin (1912-1961), trata-se não apenas da ressignificação do conceito de tradução, mas de si mesmo. A não tradução de Robin nomeia um discurso ambivalente que remete a um ato à margem enquanto nega a tradução e a si mesmo quando no fundo deseja afirmá-la e afirmar-se.

Este ensaio analisa os comentários de Robin apresentados na rádio junto com suas poesias traduzidas privilegiando a mise en scène do discurso à margem da escrita tradutória, onde a presença do eu que se expõe, ao mesmo tempo em que se quer autoral, denuncia um instante efêmero de libertação da exigência de escrever a própria obra. A reflexão atual toma como paradigma a proposta da figura emblemática da "margem" a fim de sugerir que o excesso que transborda na retórica idealista robiniana exibe a paixão/pulsão latente que subjaz num projeto que se pretende lúcido.

Desde a publicação de seu primeiro livro - uma coletânea com 14 poemas seus e outros 16 traduzidos, intitulada Ma Vie sans Moi (1940) -, Robin quis que as traduções fossem apresentadas como obras de sua própria autoria, e inclusive que não se 
pudesse fazer a diferença entre as duas. Em seguida, deu definitivamente prioridade às traduções, tanto nas publicações quanto nos programas de poesia na rádio.

Hoje, além do precioso sítio na Internet criado pelo professor bretão Jean Bescond (disponível em http://armandrobin.org/), as publicações mais relevantes da obra do poeta são aquelas organizadas pela pesquisadora Françoise Morvan, que teve o mérito principal salvar do esquecimento um material inestimável, na medida em que atentou especialmente para aquela que foi a experiência mais original desse escritor: os programas radiofônicos de poesia. Morvan publicou os textos referentes aos programas com o mesmo título que Robin lhes havia dado na rádio: Poésie sans Passeport (1990), e ela revela em seu prefácio que Robin e sua equipe de atores e professores encenavam poemas traduzidos por meio da leitura simultânea de texto original estrangeiro e texto traduzido para o francês, às vezes por justaposição, outras por superposição de vozes, provocando um estranho efeito sonoro.

Tal experiência remete, de imediato, a uma acentuação intencional do mito da tradução como união mística do poeta e de seu tradutor e está fortemente impressa nos discursos sobre a tradução poética de Robin. Mas há outro aspecto particularmente interessante nessa experiência: a obsessão de Robin pelos sons do poema, pois tanto sua experiência na rádio quanto seus comentários sobre a tradução indicam uma concepção poética que busca "traduzir" o fundo oral das línguas. Robin dizia que um poema é feito de sons, falava de "objetos sonoros", o que abre um novo horizonte para a problemática linguageira do poeta, na medida em que essa oralidade está profundamente ligada a uma pulsão, que por sua vez remete ao desejo inconsciente de sua verdadeira língua materna - o bretão.

A questão da pulsão tradutória foi sucintamente abordada por Antoine Berman em sua obra prima A prova do estrangeiro 
(2002), no momento em que ele convoca o poeta bretão para ilustrar sua teoria do politradutor com o objetivo de "examinar brevemente como a pura visada ética da tradução articula-se com outra visada - a visada metafísica da tradução e, correlativamente, com o que se pode chamar de a pulsão do traduzir" (p. 22, grifos do autor). ${ }^{4}$ A questão ética é alinhavada à discussão sobre a situação "psíquica" do sujeito tradutor, a partir da qual Berman sugere que a visada metafísica da tradução corresponde à busca romântica da pura linguagem, tal como ela havia sido evocada por Walter Benjamin no célebre prefácio às suas traduções de Baudelaire, A tarefa do tradutor.

Alguns anos mais tarde, Berman mostrou possuir profunda consciência da complexidade e do ineditismo da questão quando, em sua obra publicada postumamente Pour une critique de traductions: John Donne (1995), expressou a ignorância sobre o assunto: "O que é essa pulsão? Qual é a sua especificidade? Ainda o ignoramos, não havendo ainda uma 'teoria' do sujeito traduzinte. Sabemos unicamente que ela está no princípio de todos os destinos de tradução" (1995, p. 74-5, nota 83). De fato, a psicanálise freudiana vê na pulsão sexual um pólo necessariamente presente no conflito psíquico, pois é o objeto privilegiado do recalcamento no inconsciente; além disso, segundo Laplanche e Pontalis (1992), a pulsão sexual está estreitamente ligada a um jogo de representações ou fantasias que a especificam. A pulsão tomada em seu desejo de representação, como uma mise en scène, foi particularmente explorada na tese de doutorado sobre o poeta Armand Robin. ${ }^{5}$

O presente artigo aborda a problemática apontando para o viés filosófico presente no discurso do poeta tradutor, uma vez que se constatou que o mesmo está permeado por um pensamento metafísico; ao mesmo tempo, acena para a importância do viés psicanalítico. $O$ ponto de aderência entre as abordagens psicanalítica e filosófica da questão da pulsão tradutória está no fato de 
que ambas remetem ao mito da língua única, seja em referência à origem primitiva da linguagem (adâmica ou edênica), seja à sua visada final messiânica e universalista, seja em referência à língua materna como a experiência afetiva inaugural de prazer/identificação. Embora o apelo metafísico em direção a um idealismo poético seja o elemento aparentemente mais expressivo da concepção tradutória de Robin - a chamada não tradução -, este artigo pretende investigar a intenção mais violenta que subjaz neste discurso marginal ao mesmo tempo lúcido e apaixonado.

\section{Não tradução como renomeação}

Se, na maioria dos casos, a questão da renomeação remete à definição de uma concepção poética particular, a problemática para Robin é muito mais complexa: ele chega a não admitir, e mesmo a negar, que o que faz seja chamado de tradução, assim seus dois volumes mais expressivos intitulam-se: Poésie non traduite, Poésie non traduite II. Historicamente, essa rebeldia do tradutor que se quer autor evidencia o sentimento de ameaça que a noção tradicional de tradução implica para o trabalho criativo dos poetas e cuja reação imediata se expressa nas renomeações, a partir das quais eles constroem um discurso estratégico em favor de uma "co-autoria". Já no ensaio sobre a tradução de 1962, Da tradução como criação e como crítica, Haroldo de Campos define a tradução como "recriação, ou criação paralela, autônoma, porém recíproca", constituindo "o avesso da tradução literal" (p. 35). Armand Robin, por sua vez, afirma em Poésie non traduite II (1958): "A meu ver, não há tradução, mas criação, e criação graças à literalidade absoluta" (p. 165, grifo meu).

Embora as concepções no que se refere à questão da "literalidade" não sejam as mesmas, as renomeações guardam em comum a (nem sempre) dissimulada supervalorização radical da tradução que se opõe à sua histórica desvalorização, o que, no 
limite, corre o risco de trair uma consciência ética que pretende estar fundamentada na noção de alteridade.

Vale lembrar que a proposta modernista brasileira da antropofagia tenta realizar, pelo ato simbólico de canibalismo cultural, uma apropriação positiva do outro, pois embora "monstruosa" porque transformante - busca ressaltar o elemento original e criativo desse ato. No caso de Haroldo de Campos, a transcriação é aclamada e permanece triunfante e o seu modo antropofágico é tão auto-suficiente que quase nunca "deglute" obras inteiras, e permite-se selecionar e traduzir apenas os fragmentos que lhe agradam. Suas escolhas, em geral, recaem sobre os cânones - Pound, Joyce, Mallarmé, Maiakovski, Goethe, Dante, Homero, Octavio Paz, o texto hebraico da Bíblia e outros. Bem ao contrário de Robin que, na maioria dos casos, buscou autores desconhecidos pelos franceses e pelos ocidentais, poemas em línguas raras e longínquas.

Robin, ao tentar negar veementemente que traduz, demonstra uma inconfessada e incômoda nostalgia que remete à histórica desvalorização do sujeito tradutor. Embora explore estrategicamente, em vários momentos de sua retórica, uma necessidade vital do outro, Robin não consegue transformar essa necessidade em poder de auto-afirmação, nem no plano teórico, nem no plano existencial. Antoine Berman comenta a respeito dessa atitude do tradutor:

No plano psíquico, o tradutor é ambivalente. Ele quer forçar dos dois lados: forçar a sua língua a se lastrear de estranheza, forçar a outra língua a se de-portar em sua língua materna. Ele quer ser escritor, mas não é senão re-escritor. Ele é autor - e nunca o Autor. Sua obra de tradutor é uma obra, mas não é A Obra. (2002, p. 18-9)

A não tradução assim renomeada, re-negada, denegada, alimenta na verdade um jogo subliminar, dramatizado nessa crônica marginal que são os comentários apresentados por Robin 
nos programas radiofônicos de poesias traduzidas de 18 línguas. "Como chamaríamos esse discurso"? É o que indaga Roland Barthes, em Roland Barthes por Roland Barthes: "Erótico, sem dúvida, pois ele tem a ver com gozo; ou talvez ainda 'estético', se previrmos submeter pouco a pouco essa velha categoria a uma ligeira torção, que a afastará de seu fundo regressivo, idealista, e a aproximará do corpo, da deriva" (apud Manuel da Costa Pinto, Folha de S.Paulo, 14/06/2003).

\section{Poésie sans passeport}

O título do programa na rádio denuncia sua tendência universalista, confirmada pela atmosfera fusional estrategicamente ensaiada para a leitura dos poemas: confundindo a leitura de sua própria tradução com a do poema reproduzido em sua língua de origem, ele alterna, superpõe, tece juntamente as vozes numa dicção vertiginosa e inaudível que pretende reencontrar na linguagem poética universal uma espécie de idioma pré-babélico, ou o "mundo de uma voz" (remetendo ao título da coletânea póstuma de seus poemas e fragmentos Le Monde d'une voix).

Vejamos os comentários de Robin por ocasião da primeira apresentação na rádio, referentes à tradução do poema Sur la cime des miracles, do poeta húngaro André Ady:

Os dois textos, o húngaro e o francês são aqui os mesmos no espírito e em literalidade. Mas me parece que eles podem viver unidos e separados, idênticos e diferentes; eles não são mais um do outro; um e outro pertencem a não sei qual sopro superior que passa sobre eles e que os leva para um reino onde não há mais nem francês nem húngaro, e onde a noção de tradução não tem mais nenhum sentido. (p. 46)

Tomados isoladamente, tais comentários tendem a ser facilmente interpretados como a evocação de uma ascese espiritual, 
de um nirvana, caracterizando a encenação do mito sustentador da inspiração poética e da utopia da língua única. Vemos, no entanto, nas apresentações de poesia na rádio, manifestar-se mais explicitamente essa loucura das línguas onde se dissolve o eu identitário. O recobrimento da língua materna - o bretão - pelo francês constrói uma figura palimpséstica do sujeito que almeja ocultar-se na camada mais profunda e reconstruir um texto isento de traços e restos de si, inteiramente "outro".

Morvan (ROBIN, 1990) comenta, com perspicácia, como o poeta bretão "se apraz em acentuar o mito da tradução como união mística do poeta e de seu tradutor [porque] este trabalho singular tende, com efeito, à fusão, dando em seus melhores momentos uma percepção oceânica das línguas", (p. 30). Morvan definiu a busca compulsiva de Robin pelo poema dos outros como uma "brincadeira metafísica" na medida em que "Ihe permite brincar com sua vida encoberto por outros que nunca são outros e por poemas que nunca são nem deles nem dele: o que ele chama 'não tradução' consiste em respeitá-los apenas para transformálos". (p. 18)

Embora pareça haver, de fato, nesse jogo, um apelo metafísico que convém a Robin, se atentarmos para a palavra jogo em francês, jeu, e considerarmos esse jogo como uma representação, obtemos, por sua possibilidade homofônica, um dado a mais, um "eu": jeu/je. A representação de um eu que participa desse jogo da não-tradução não só torna a experiência mais interessante, mas provoca uma indagação acerca da instância em que essa experiência se inscreve enquanto "ato de linguagem". Mais do que constatar um duplo jogo (jeu/ie), trata-se de situar a prática desse ato de tradução ao lado de seu ato de fala na rádio. Felizmente, isso foi possível na medida em que essa fala não foi alterada pelo ato de transcrição posterior, pois segundo Roland Barthes "O ato de fala é sempre tático [...] no momento em esta [a fala] é passada a escrito, é a própria inocência daquela tática [...] que 
apagamos; a inocência está sempre exposta" (Do ato de fala ao ato de escrita, 1975, p. 4).

\section{Um corpo à margem}

Se, por um lado, a tradução e o tradutor foram tradicionalmente deitados à margem (abandonados, desprezados), podese ler nos discursos marginais que os acompanham o que diz respeito ao ensejo - tão próximo de um desejo -, de garantir, à margem da tradução-já-margem-do-texto-do-outro o seu corpo, a sua própria presença. Diferentemente dos tradutores "humildes", o discurso marginal que é a não-tradução expõe um modo de existência que permite ao poeta tradutor exteriorizar "de uma maneira histérica", como diz Barthes em Do ato de fala ao ato de escrita (1975), aquilo que, no ato de escrita ("forma castradora" da espontaneidade"), o obriga a ser "comedido" e preciso, sujeito dividido entre pensar mais em função da verdade do texto do que em função da imagem de um eu que se quer representar.

Quando Robin acrescenta, ao falar de literalidade, que "não há só o sentido, há o som, há o número de sílabas, há o ritmo e também há a rima" (Poésie non traduite II, 1958, p. 165), percebe-se a sua obsessão pela fidelidade ao texto original; porém, em meio a traduções brilhantes e originais (transformadoras do francês e do outro), o sujeito Robin irrompe, toma a palavra e invade a cena com um discurso irracional, cujas estratégias retóricas são impregnadas de arbitrariedades e subjetividades. Robin lança um questionamento especulativo acerca do que "racionalmente" seria considerado como "tradução", apresentando a "sua" verdade individual, sem chegar, portanto, a elaborar um ensaio teórico-crítico nos moldes de uma concepção clássica de "discurso filosófico". Vejamos um exemplo referente ao programa de poesia sueca: 
A tradução não somente não é possível, ela não é concebível; mais exatamente ainda, ela não tem razão de ser; não há algo que se possa chamar tradução de um poema de uma língua para outra, há o mesmo poema em todas as línguas, todos os países, todos os tempos; há supressão da tradução. (Poésie sans passeport, p. 69)

Robin clama a impossibilidade da tradução apelando para um universalismo: "há o mesmo poema em todas as línguas", mas é justamente a busca de semelhanças que "impossibilita" a tradução literária, uma vez que a identidade desse novo texto é obtida a partir de uma alteridade, das diferenças que o outro the imprime. Não pode haver o mesmo poema em todas as línguas da maneira que sugere Robin, suprimindo as diferenças entre elas, como se a tradução alcançasse uma língua superior que as tornasse idênticas.

Embora Robin acredite poder iludir-se e iludir-nos com a sua mise en scène, é necessário investigar o que há de subliminar nesse jogo, o que seu discurso dissimula. $O$ confronto entre os dois modos de existência da atividade literária no rádio - o comentário e a tradução dos poemas - sugere, portanto, um entendimento maior do eu profundo de Robin. $O$ discurso da não-tradução, essa não-tradução comentada em voz alta, pela sua forma de apresentação histérica, parece remeter a uma experiência que estaria primordialmente associada a um exercício místico tanto quanto psicanalíitico - um e outro designam o que a linguagem humana não pode apreender, ou seja, uma verdade subjetiva que se opõe à objetividade da verdade exigida idealmente num discurso filosófico. Foi assim que a busca de nos caminhos de análise em torno do caso específico do discurso robiniano levou-nos a acrescentar aos axiomas místicos e metafísicos dessa questão uma reflexão mais próxima da dimensão humana, de uma psicanálise. 


\section{Tradução como libertação}

Considerando o fenômeno repetitivo da pulsão, caberia apontar para a palavra em francês, répétition, que também evoca ensaio teatral, musical. $O$ ensaio, como no teatro, é um exercício cuja repetição (répétition) pode ser uma "cura, uma salvação". Klossowski, comentando a "admirável tradução da Eneida" lembra que "a psicanálise nos ensinou que nossa doença era a repetição, mas que também nos curávamos pela repetição (apud Deleuze, 1975, p. 295). O politradutor, ao mesmo tempo em que é vítima da pulsão, do desejo de repetição, é só por ela que se redime.

Essa experiência "escrita em voz alta", remetendo às palavras de Barthes em O prazer do texto (1983) é "aquela que procura os incidentes pulsionais, a linguagem revestida de pele, um texto onde se possa ouvir o grão da garganta, a pátina das consoantes, a voluptuosidade das vogais, toda uma estereofonia da carne profunda: a articulação do corpo, da língua, e não a do sentido, da linguagem" (p. 116, grifo meu). Vale ouvir Robin no rádio:

Caminhando de era em era, combatendo-me a cada passo, fiz-me todos os grandes poetas de todas as línguas. Atingi um Éden de antes da Torre de Babel: lá todos falavam uma além-língua; arado ligeiro, minha alma tropeçou de cepa em cepa ao longo da palavra íntegra. Percebi-me geral e universal. Fui feliz.

Eles-eu somos UM. Não estou diante deles, eles não estão diante de mim. Falam antes de mim em minha garganta, aprisiono suas gargantas com minhas palavras futuras. Praticamos juntos som a som, sílaba a sílaba, ritmo a ritmo, sentido a sentido, e sobretudo, destino a destino, unidos e separados em sangue e lágrimas, ontologicamente sem felonia eles-eu, UM intacto (1990, p. 32).

Uma vez que, a propósito, falamos de rádio, cabe evocar um fenômeno comentado por Lecercle (1996), a que ele chama 
de tradusom, isto é, a tradução a partir do som, e não do sentido: para Lecercle, "a tradusom nos fornece um exemplo brilhante do trabalho do resto": "o resto é o lugar lingüístico onde o corpo do sujeito se diz, onde a censura vira de costas, onde a violência do afeto se deixa perceber" (p. 94). O resto desse eu que quer calar, repelir sua própria voz comparece à revelia no excesso que pulsa, selvagem, na escrita tradutória e se exalta na margem discursiva resto que revela uma identidade.

A não tradução de Robin, embora evidencie um idealismo poético no discurso - seja quando da exposição eloqüente, mas dissimulada do sujeito autoral, seja quando do processo de apropriação do outro e recriação do texto literário -, possibilita visualizar a dimensão libertadora dessa crônica marginal.

Nesse sentido, merece ser destacada nessa experiência de Robin na rádio uma radical mudança na abordagem do poema em seu estatuto mesmo de obra de arte. O poema, aquele objeto cultuado e intocável, bibelô inanimado e mudo, passa a existir enquanto manipulável, interpretável, adquirindo uma verdade transitória e, no entanto, viva: todo o contrário do livro escrito. Barthes (1975) o compara à "preparação de um morto [...] embalsamamos aquilo que dizemos, como faríamos a uma múmia, de modo a torná-lo eterno" (p. 3).

De certa forma, Robin acaba por mostrar, pelo recurso ao som, que as imagens do poema são abrigos precários, e é aí que se pode compreender, a meu ver, a "verdade" de sua poesia não traduzida, pois aponta para esta antinomia que comparece na articulação entre o desejo de fidelidade absoluta - expresso na retórica da não tradução - e a realidade da diferença impura que contamina inexoravelmente suas traduções. 
CHANUT, Maria Emília P. Armand Robin e a não tradução

\section{Bibliografia}

BALCOU, J. BESCOND, J. COMBOT, P. Armand Robin: La quête de I'universel. Morlaix: Editions Skol Vreizh, 1989.

BARTHES, Roland Roland Barthes par Roland Barthes. Paris: Sevil, 1975.

Do ato de fala ao ato de escrita, in: Tempo Brasileiro 41. Trad. de Olívia Gomes Barradas. Abril-junho 1975.

. O Prazer do Texto. Lisboa: Edições 70, 1983.

BERMAN, Antoine. L'Epreuve de l'étranger - Culture et traduction dans I'Allemagne romantique. Paris, Gallimard, 1984. 1995.

Pour une critique des traductions: John Donne. Paris, Gallimard,

. A prova do estrangeiro. Cultura e tradução na Alemanha romântica. Trad. de Maria Emília P. Chanut. Bauru, SP: EDUSC, 2002.

CAMPOS, Haroldo de. Da tradução como criação e como crítica. Tempo Brasileiro, 1962.

DELEUZE, Gilles. Lógica do sentido. Trad. Luiz Roberto S. Fortes. São Paulo: Perspectiva, 1975.

LECERCLE Jean-Jacques. La violence du langage. Paris: Presses Universitaires de France, 1996.

ROBIN Armand. Poésie Non Traduite. Paris: Gallimard, coll. Blanche, 1953.

. Poésie Non Traduite II. Paris: Gallimard, coll. Blanche, 1958.

. Le monde d'une voix. Paris: Gallimard, coll. Poésie, 1970.

. Ma vie Sans Moi. Paris: Gallimard, coll. Poésie, 1970.

. Ecrits Oubliés II. Traductions. Rennes: Ed. Ubacs. Texte établi et présenté par Françoise Morvan, 1986.

Poésie sans Passeport. Rennes: Ed. Ubacs. Texte établi et prés. par F.Morvan, 1990.

Quatre Poètes Russes (Maïakovski, Pasternak, Blok, Essénine).

Paris: Ed. Le temps qu'il fait 1985 (bilíngüe) - Reedição 1991.

SHAKESPEARE W. (Trad. Armand Robin) Le Roi Lear (bilíngue). Paris: Flammarion, 1995. 
Poemas de Armand Robin. In: Fragments. Paris: Gallimard, 1992. Texte établi et présenté par Françoise Morvan.

\title{
Traduzidos por Maria Emília Pereira Chanut
}

\author{
SEM PAÍS \\ O ÁRABE
}

Em minha voz a areia fazia sílabas

E um ruído de garganta enfim encontrou água;

Um ávido resmungo poeirento ofegou em minhas palavras;

De onde brilha o Corão tomei o ritmo da lua

Para deslizar longe de mim de duna em duna.

Conheci

no Imroulqaïs, Chanfara,

Viravoltas sábias e selvagens

Presa, precipitada, retomada,

Banhei na miragem das areias minha miragem de sol.

Ritmo duro e puro

De retorno contra si pelo vento!

Beleza concentrada em branco

Monótona em seu ódio ofuscante.

Poemas escritos de oásis em oásis

Por grandes placas isoladas desesperadamente 
CHANUT, Maria Emília P. Armand Robin e a não tradução

Em segredo dava a meus cantos nomes de ventos;

O longo, o prolongado, o extenso, o vibrante, o hesitante, O contínuo, o leve, o impaciente.

Andei dificilmente nessa língua,

poema e seus jarros bebiam em mim como uma sede Em toda parte, atrás de mim, à direita, à esquerda A ameaça de uma morte branca.

\section{SANS PAYS}

L'ARABE

Dans ma voix le sable faisait des syllabes

E† j'eus un bruit de gorge qui trouve enfin de l'eau;

Un âpre râle poussiéreux haleta dans mes mots;

Je pris le rythme de lune dont brille le Coran

Pour glisser loin de moi de dune en dune

J'ai connu,

dans Imroulqaïs, Chanfara,

Des virevoltes savantes et sauvages:

Prise, précipitée, reprise,

J'ai baigné dans le mirage des sables mon mirage de soleil 
Rythme dur et pur,

Retourné contre soi par le vent!

Beauté concentrée en blanc,

Monotone en sa haine aveuglante

Poèmes écrits $d$ 'oasis en oasis,

Par grandes plaques isolées désespérément

En secret je donnais à mes chants des noms de vents:

Le long, le prolongé, I'étendu, le vibrant, le tremblant,

Le continu, le léger, l'impatient.

J'ai marché difficilement dans cette langue,

Le poème et ses brocs puisaient en moi comme une soif.

Partout, devant, derrière moi, à droite, à gauche

La menace d'une mort blanche

\section{TU FU}

Há mais de mil anos, no não-tempo do canto,

Errando sem mim, sem minha vida, encontrei Tu fu gritando.

Longe de todo país, de todo tempo, ficamos amigos no mesmo instante.

Ele ajudou meu junco de instantes oscilantes

Foi, mais duro que eu, meus instantes lancinantes. 
CHANUT, Maria Emília P. Armand Robin e a não tradução

Nas ruínas de Tchang-Ngang minha pátria possuí

De cidade em cidade com ele eu fugi.

Tinha sobre ele os massacres, as ruínas, a guerra.

Agradar ele não soubera.

\section{TOU FOU}

Il ya plus de mille ans, dans le non-temps du chant, Errant sans moi, sans ma vie, j'ai rencontré Tou fou criant.

Loin de tout pays, de tout temps, nous fûmes amis à l'instant.

II aida ma jonque d'instants oscillants, Il fut, plus dur que moi, mes instants déchirants.

Dans les ruines de Tchang-Ngang i'eus ma patrie, De village en village avec lui j'ai fui.

II avait sur lui les massacres, les ruines, la guerre, Il ne savait pas plaire. 


\section{VIDA COM TODAS AS OUTRAS VIDAS \\ (VIDA SEM NENHUMA VIDA)}

Todas as outras vidas estão na minha vida,

Pelas nuvens nuvem presa,

Riacho de relva em relva surpreso,

Fugi de vida em vida,

Pressa nunca arrefecida.

Do tempo estarei à frente,

Farei-me flutuante, movente,

Serei uma truta de prata somente.

\section{VIE AVEC TOUTES LES AUTRES VIES \\ (VIE SANS AUCUNE VIE)}

Toutes les autres vies sont dans ma vie,

Par les nuages nuage pris,

Ruisseau d'herbe en herbe étourdi,

Je me fuis de vie en vie,

Hâte sans fin rafraîchie.

Je dépasserai le temps,

Je me ferai mouvant, flottant,

Je ne serai qu'une truite d'argent. 
CHANUT, Maria Emília P. Armand Robin e a não tradução

TECIDO

Sou fabricado em tecido popular,

Tenho os gestos das fiandeiras proletárias em meus gestos

Lancei por quatro anos minh'alma em todas as línguas

Busquei, livre e louco, todas as palavras não domadas

Indiferente ao terno céu, aos pássaros, às nuvens amigas

Fiquei muito longe de mim bloqueado

Em minha cidadela de palarras humanas.

Mais emocionantes que o céu,

Mais coloridas que meus antigos prados

Não foram mais minhas paisagens que fiz passar

Mas as palavras de todos os homens, as palavras de liberdade.

\section{ÉTOFFE}

Je suis fabriqué dans une étoffe populaire,

J'ai les gestes des fileuses prolétariennes dans mes gestes,

J'ai jeté pendant quatre ans mon âme dans toutes les langues,

J'ai cherché, libre et fou, tous les mots non domptés,

Indifférent au tendre ciel, aux oiseaux, aux amis nuages,

Je me suis très loin de moi bloqué

Dans ma citadelle de paroles humaines. 
Plus émouvantes que le ciel,

Plus colorées que mes anciens prés

Ce ne fut plus mes paysages que je fis passer,

Mais les mots de tous les hommes, les paroles de liberté.

COM GRANDES GESTOS...

Com grandes gestos,

Lancei durante quatro anos minh'alma em todas as línguas,

Busquei, livre e louco, todos os lugares de verdade.

Sobretudo procurei os dialetos em que o homem não era domado.

Pus-me em busca da verdade em todas as línguas.

martírio de meu povo era-me proibido

Em francês.

Tomei o croata, o irlandês, o húngaro, o árabe, o chinês

Para me sentir um homem liberto.

quanto mais eu gostava das línguas estrangeiras

Para mim puras, tão à parte:

Em minha língua francesa (minha segunda língua) houvera todas as traições.

Diziam sim à infâmia

Nela sabiam dizer sim à infâmia! 
CHANUT, Maria Emília P. Armand Robin e a não tradução

Senti o martírio de meu povo nas palavras de todos os países

Sofri em bretão, francês, norueguês, tcheco, esloveno, croata;

E sobretudo em russo:

Estendi-me sobre a grande terra russa,

Ouvia os cantos de um povo imenso

que bem queria morrer

E lá, crucificado, não sentia dor,

Lá, cansado, sentia apenas o orvalho,

Lá, cansado de mim, sentia-me repousado

Lá, fatigado, senti tudo orvalhado.

\section{AVEC DE GRANDS GESTES...}

Avec de grands gestes,

J'ai jeté pendant quatre ans mon âme dans toutes les langues,

J'ai cherché, libre et fou, tous les endroits de vérité,

Surtout j'ai cherché les dialectes où l'homme n'était pas dompté.

Je me suis mis en quête de la vérité dans toutes les langues.

Le martyre de mon peuple et de tout peuple, on m'interdisait

En français. 
J'ai pris le croate, l'irlandais, le hongrois, l'arabe, le chinois Pour me sentir un homme délivré.

$J^{\prime}$ aimais d'autant plus les langues étrangères

Pour moi pures, tellement à l'écart:

Dans ma langue française (ma seconde langue) il y avait eu la trahison, toutes les trahisons

On y disait oui à l'infamie.

On savait y dire oui à l'infamie!

J'ai senti le martyre de mon peuple dans les mots de tous les pays:

J'ai souffert en breton, français, norvégien, tchèque, slovène, croate;

E sobretudo em russo:

Je me suis étendu sur la grande terre russe,

J'entendais les chants d'un peuple immense

qui voulait bien mourir

Eł là, crucifié, je ne sentais pas de mal,

Là, fatigué, je ne sentais que de la rosée,

Là, fatigué de moi, je me sentais reposé

Là, fatigué, j'ai tout senti en rosée 
CHANUT, Maria Emília P. Armand Robin e a não tradução

\section{TRADUÇÃO}

Pela escolha das palavras

Reproduzir uma alma paralela

Estar com ela até o fim de sua rota

A voz de sofrimento do mundo inteiro

É por toda parte monótona.

Só há uma única salmódia.

E é monótono no início

Depois vem a estrada.

De outra em outra eu transito.

\section{TRADUCTION}

Par le choix des mots

Reproduire une âme parallèle,

Etre avec elle jusqu'au bout de sa route

La voix de souffrance du monde entier

Est partout monotone.

II n'y a qu'une seule psalmodie.

E† d'abord c'est monotone

Puis vient la route

D'autre en autre je foisonne! 


\section{CANTOS RUSSOS}

Uma terra lancinante, uma terra que dança e canta

E sabe viver e sabe morrer.

Volga, rio de um poema de milhares de anos,

Embalando com prados cem pátrias

Maternal mãe do mundo inteiro.

Carregador de pão, andrajoso maravilhoso,

Não é mais uma pátria, é um canto

De gel, de vento, de neve, de coragem.

\section{CHANTS RUSSES}

Une terre poignante, une terre qui danse et chante

Et sait vivre et sait mourir.

Volga, fleuve d'un poème de milliers d'ans,

Berçant de steppes cent patries,

Maternelle mer du monde entier.

Porteur de pain, loqueteux merveilleux,

Ce n'est plus une patrie, c'est un chant

De gel, de vent, de neige, de courage. 
CHANUT, Maria Emília P. Armand Robin e a não tradução

\section{TEXTOS SELECIONADOS EM Armand Robin: \\ La quête de l'universel (1989) \\ O ILETRADO}

Diante dos bosques, dos trigos, era tolo beato.

O que não se lê eu lia:

As nuvens, os ventos, os rochedos, a folia

Da lua nos matos.

E o céu com seu grande lago em arco

Onde o sol dia todo seu seixo aumenta,

Onda por onda, e o esboroamento movente

Das nuvens de mim dispunha.

As árvores giravam em mim lentamente

Suas páginas ora barulhentas, ora mudas,

Ora espessas e amareladas, as estações

Davam-me lições. 


\section{L'ILLETRÉ}

Devant les bois, les blés j'étais béat benêt.

Je lisais ce qui ne se lit pas:

Les nuages, les vents, les rochers, les ébats

De la lune dans les bois.

Eł le ciel avec son grand étang courbé

Où le soleil tout le jour accroît son caillou,

Onde par onde, et le déferlement changeant

Des nuages disposaient de moi.

Les arbres tournaient lentement en moi

Leurs pages tantôt bruyantes, tantôt muettes,

Tantôt épaisses et jaunies, les saisons

Me donnaient des leçons. 
CHANUT, Maria Emília P. Armand Robin e a não tradução

\section{MORTE DE UMA ÁRVORE}

A fazenda onde nasci sem saber está partindo, Mãe, mãe; ela pôs como tu sua touca de domingo; O rastelo que é minh'alma prendeu-se entre as cepas; A terra, nutridora dos poemas, está sem cultivo; Afagará ela no verão a nobre sesta das avelas?

Por que, bordada em lua, a escolta de margaridas, Titubeando sobre as silvas dos taludes hirsutos, Agarra-se ela às pernas moles do crepúsculo? E eu, que faço aqui, imóvel, taciturno, meu ser trespassado desta árvore sem vida?

\section{MORT D'UN ARBRE}

La ferme où je suis né s'en va sans connaissance Mère, mère; elle a mis comme toi sa coiffe du dimanche La herse qu'est mon âme s'est prise entre les souches; La terra, nourricière des poèmes, reste em friches; Bercera-t-elle cet été la noble sieste des gerbes?

Pourquoi, brodée de lune, l'escorte des marguerites, Titubant sur les ronces des talus hirsutes, S'accroche-t-elle aux jambes molles du crépuscule? 
Et, moi, que fais-je là, taciturne, immobile,

Avec cet arbre mort en travers de mon être?

(SEM TÍTULO)

Há mais de dez anos meus gestos estão destruídos,

Muito só, longe do poema, em um bosque isolado,

Sobressalto-me com o machado, mudo, desertado,

$\mathrm{E}$ os poemas que às vezes de mim despencam

Fazem apenas o ruído de uma folha morta nos matos.

Homem da noite,

Vivi num mundo destruído;

Palavras, gestos tiveram que trepar de ruína em ruína.

Depuis plus de dix ans mes gestes sont détruits,

Très seul, loin du poème, en un bois deserte,

Je m'assaille à la hache, muet, deserte,

Et les poèmes qui parfois tambent de moi

Font à peine le bruit d'une feuille morte dans les sous-bois

Homme de la nuit,

J'ai vécu dans un monde détruit;

Mots, gestes ont dû grimper de ruine en ruine. 
CHANUT, Maria Emília P. Armand Robin e a não tradução

\section{A OFERTA SEM DEMANDA}

Hoje de novo preciso derramar

Minh'alma a vocês em tinta escolar

Que faz nos aventais manchas duras de amar.

Surjo apenas dos iletrados;

Ao menos malgrado os livros não sou letrado; Não sei ser um civilizado.

Não sou "antes", não sou "durante", não sou "depois";

Sou nômade e não contemporâneo;

Estou com todos vocês, mas enevoado. 


\section{L'OFFRE SANS DEMANDE}

Aujourd'hui de nouveau j'ai besoin de verser Mon âme devant vous en encrier d'écolier

Qui fait sur lês tabliers des taches difficiles à aimer

Je surgis à peine des illetrés;

Du moins malgré les livres je ne suis pas lettré;

Je ne sais pas être un civilisé.

Je ne suis pas "avant", je ne suis pas "pendant", je ne suis pas "après";

Je suis nomade et non contemporain;

Je suis avec vous tous mais en nuée. 
CHANUT, Maria Emília P. Armand Robin e a não tradução

CARTA A MEU PAI

Meu pai, vejo bem que me enganei

Querendo tornar-me um poeta, um letrado;

Consegui apenas me cansar

E só zanzar, todo zangado.

Fui mais longe do que a nós é permitido;

Injuriam-me, sou odiado, escarnecido;

Onde nasci deveria ter ficado,

Todos têm razão de me ter castigado.

Hoje se viesse teria me encontrado

Como esta foice que deixou ontem à noite

Nos obscuros gramados e se recorda bem há pouco

Ter sob os teus dedos trabalhado. 


\section{LETTRE À MON PÈRE}

Mon père, je vois bien que je me suis trompé

En voulant devenir un poète, um lettré;

Je n'ai réussi qu'à me fatiguer

Et qu'à tournicoter, tout brouillé.

Je suis allé plus loin qu'à nous il n'est permis;

On m'accable de haine et de raillerie;

Où je suis né j'aurais dû rester,

Tous ont eu raison de me châtier.

Aujourd'hui si tu venais tu me retrouverais

Comme cette faux que tu as laissée

Hier soir dans dês herbes obscures et se souvient très frais

D'avoir sous tes doigts travaillé.

\section{NOTAS}

1 A coletânea póstuma publicada pela Gallimard contém apenas a parte dos poemas da primeira edição (1940) de Ma vie sans moi, tendo sido eliminadas as traduções que, originalmente, compunham o estranho livro de Robin. Reuniram-se assim, em uma só edição, os poemas dessa primeira obra, os melhores do autor, e os fragmentos póstumos, a maioria de qualidade duvidosa. Trata-se da única coletânea de poemas de Robin, que posteriormente só publicou traduções.

2 Os detalhes escabrosos da trajetória suspeita dos manuscritos de Robin são denunciados por Françoise Morvan no prefácio de Fragments (Gallimard, 1992), a qual, com esta coletânea, julga trazer ao leitor a verdade desses fragmentos: "o aspecto lapidar de textos que encontram a sua beleza no desnudamento e no abandono em que foram deixados" (p. 32).

3 As línguas e dialetos traduzidos repertoriados são: alemão, inglês, árabe, bretão, búlgaro, chinês, espanhol, finlandês, flamengo, gaulês (País de Gales), holandês, húngaro, italiano, kalmouk (Rússia), macedônio, ouighour (língua turca da Ásia Central), polonês, russo, esloveno, sueco, tcheco, tchéremisse (Rússia). Haveria possíveis traduções do hebreu, do gaélico, do japonês, do grego e do latim, entre outras. 
CHANUT, Maria Emília P. Armand Robin e a não tradução

4 As citações referentes a esta obra de Antoine Berman remeterão às páginas do título publicado em português, traduzido por mim: A prova do estrangeiro. Cultura e tradução na Alemanha romântica: Herder, Goethe, Schlegel, Novalis, Humboldt, Schleiermacher, Hölderlin. (2002). O título original em francês é: L'épreuve de l'étranger. Culture et traduction dans I'Allemagne romantique. Paris: Gallimard, 1984.

5 Tese defendida pela autora deste artigo em 02 de abril de 2004, no Instituto de Biociências, Letras e Ciências Exatas - IBILCE (UNESP - Campus de São José do Rio Preto). 